\title{
Investigating the Consistency Between Pre-Operative Planning and Surgical Implementation for Degenerative Lumbar Spine Surgery
}

\author{
Dejeneratif Lomber Omurga Cerrahisi İçin Ameliyat \\ Öncesi Planlama ile Cerrahi Uygulama Arasındaki \\ Tutarlılığın Araştııılması
}

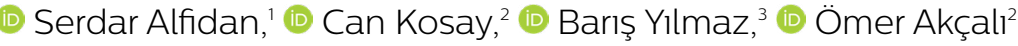

1Private Antalya Memorial Hospital, Antalya, Turkey ${ }^{2}$ Department of Orthopedic Surgery and Traumatology, Dokuz Eylul University, Faculty

of Medicine, Izmir, Turkey ${ }^{3}$ Department of Orthopaedic and Traumatology University of Health Sciences, Fatih Sultan Mehmet Training and Research

Hospital, Istanbul, Turkey

Cite this article as: Alfidan S, Kosay C, Yilmaz B, Akçalı Ö. Investigating the Consistency Between Pre-Operative Planning and Surgical Implementation for Degenerative Lumbar Spine Surgery. Bosphorus Med J 2021;8(3):138-145.

Received: 13.02 .2021 Accepted: 05.05.2021

Correspondence: Dr. Serdar Alfidan. Özel Antalya Memorial Hastanesi, Antalya, Turkey Phone: +905055398817

e-mail: serdaralfidan@icloud.com

\section{ABSTRACT}

Objectives: We aim to establish and investigate the correlation between the pre-operative planning performed based on the pre-operative findings and the interventions performed during the surgery.

Methods: Sixteen patients with degenerative lumbar spine disorder who decided to be operated on by four orthopedics and traumatology specialists were included in the study. The inclusion criteria for patients were 2-fold: Development of spine disorder requiring surgery in the lumbar region on a degenerative basis and consideration of posterior spinal instrumentation at least in a level by the surgeons. Spine disorders developing secondary to congenital, traumatic, pathological, and infective etiologies were excluded from the study. Titanium alloy (Ti-6A1$4 \mathrm{~V}$ ) spinal instrumentation sets were used in the surgeries of all patients. To provide standard statistical analysis for the study, an assessment form consisting of 162 questions related to the patient complaints, clinical findings, results of radiographic examination, and the surgery planned was prepared.

Results: A strong kappa consistency was also found for interventions of discectomy, laminectomy, flavum excision, and posterior spinal instrumentation. An intermediate kappa consistency was found for foraminotomy and foraminectomy. It was found that findings of claudication and radiculopathy were completely inefficient in preoperative planning; on the other hand, findings of the narrowing of the spinal canal interpreted with magnetic resonance imaging were highly efficient in pre-operative planning. Finally, it was determined that pre-operative planning performed for the level of L5-S1 of the lumbar spine region was much more inconsistent compared to the other levels of the lumbar spine region.

Conclusion: Findings of claudication and radiculopathy had no contribution to the planning, but the magnetic resonance imaging findings were valuable. Performing foraminotomy and foraminectomy at any surgical level or determining any surgical procedure that would be performed at the L5-S1 level with a pre-operative planning were found to potentially contain error.

Keywords: Degenerative spinal disorder; pre-operative planning; surgical decision.

\section{ÖZET}

Amaç: Ameliyat öncesi bulgulara göre yapılan ameliyat öncesi planlama ile ameliyat sırasında yapılan girişimler arasındaki ilişkiyi kurmayı ve araştırmayı hedefliyoruz.

Yöntem: Çalışmaya dört Ortopedi ve Travmatoloji uzmanı tarafından ameliyat edilmesine karar verilen dejeneratif lomber omurga bozukluğu olan 16 hasta dahil edildi. Hastalar için dahil edilme kriterleri iki yönlüydü: lomber bölgede dejeneratif temelde ameliyat gerektiren omurga bozukluğunun gelişimi ve en azından cerrahlar tarafından 
posterior spinal enstrümantasyonun dikkate alınması. Doğuştan, travmatik, patolojik ve enfektif etiyolojilere sekonder gelişen omurga bozuklukları çalışma dışı bırakıldı. Tüm hastaların ameliyatlarında Titanyum Alaşımlı (Ti-6A1-4V) spinal enstrümantasyon setleri kullanıldı. Çalışma için standart istatistiksel analiz sağlamak amacıyla hasta şikayetleri, klinik bulgular, radyografik inceleme sonuçları ve planlanan ameliyatla ilgili 162 sorudan oluşan değerlendirme formu hazırlandı.

Bulgular: Diskektomi, laminektomi, flavum eksizyonu ve posterior spinal enstrümantasyon müdahaleleri için güçlü bir kappa tutarlılı̆ı bulundu. Foraminotomi ve foraminektomi için orta düzeyde kappa tutarlılığı bulundu. Topallama ve radikülopati bulgularının preoperatif planlamada tamamen yetersiz olduğu; manyetik rezonans görüntüleme ile yorumlanan spinal kanal daralması bulguları ise ameliyat öncesi planlamada oldukça etkili oldu. Son olarak lomber omurga bölgesinin L5-S1 seviyesi için yapılan ameliyat öncesi planlamanın lomber omurga bölgesinin diğer seviyelerine göre çok daha tutarsız olduğu belirlendi.

Sonuç: Kladikasyo ve radikülopati bulgularının planlamaya katkısı yoktu, ancak manyetik rezonans görüntüleme bulguları değerliydi. Herhangi bir cerrahi seviyede foraminotomi ve foraminektomi yapılmasının veya ameliyat öncesi planlama ile L5-S1 seviyesinde uygulanacak herhangi bir cerrahi prosedürün belirlenmesinin potansiyel olarak hata içerdiği bulundu.

Anahtar sözcükler: Dejeneratif spinal bozukluk; preoperatif planlama; cerrahi karar.

D. egenerative spinal disorder may be encountered with various clinical pictures, complaints, physical examination, and radiological findings. ${ }^{[1]}$ Despite this, objective examination findings are considerably low. ${ }^{[2]}$ Moreover, these different clinical pictures cannot be explained by advanced imaging techniques either. ${ }^{[3]}$ When sufficient benefit cannot be obtained from the conservative treatments tried at the beginning, and/or progressive neurological deficit develops, then surgical treatment becomes a current issue. ${ }^{[4]}$

In degenerative spinal disorders, the principal surgical treatment method is a decompression procedure. ${ }^{[5]}$ However, a number of surgical procedures such as laminotomy, laminectomy, discectomy, foraminectomy, and different fusion methods and levels can be performed in addition to decompression therapy. The surgeon decides which one of these methods will be performed according to patient complaints, physical examination findings, and radiographic examination findings of the patient. Nevertheless, the complaints and clinical findings of the patients, or the clinical findings and the results of radiographic examination of the patients may not be consistent with each other. ${ }^{[6]}$

In this study, considering that there could be significant differences and inconsistencies between pre-operative planning and surgical interventions performed during surgery, we aimed to detect these inconsistencies and to determine the parameters that might cause these inconsistencies.

\section{Methods}

Procedures were fully compliant with Dokuz Eylul University, Faculty of Medicine Ethical Committee approved the study. Patients with admitted degenerative lumbar spine disorder between the years 2005 and 2010 were evaluated retrospectively.

In this study, 16 patients with degenerative lumbar spine disorder who decided to be operated on by four orthopedics and traumatology specialists were included in the study. At the time of the study, the specialists each had at least 10 years of experience in spinal surgery. Eleven of the cases were female, five of them were male, and the mean age was 61.4 (45-77) years. The inclusion criteria for patients were 2-fold: Development of spine disorder requiring surgery in the lumbar region on a degenerative ground and consideration of posterior spinal instrumentation at least in a level by the surgeons. Spine disorders developing secondary to congenital, traumatic, pathological, and infective etiologies were excluded from the study. Titanium alloy (Ti-6A1$4 \mathrm{~V}$ ) spinal instrumentation sets were used in the surgeries of all patients. To provide standard statistical analysis for the study, an assessment form consisting of 162 questions related to the patient complaints, clinical findings, results of radiographic examination, and the surgery planned was prepared.

The first part of the form was filled out by the surgeons before the surgery. In this part, the surgeon was asked to note the findings for each level after evaluation of the radiogram, magnetic resonance imaging scan, and examinations of the patient. At the end of this part, the surgeon was asked to note the procedure planned to be performed for each level during surgery separately. In the first 3 post-operative days, the surgeons participating in the study were asked to fill out the second part of the form. In this part, the surgeons were asked to note the interventions performed for each level during the surgery. 
First, we determined the statistical consistency between the interventions planned by the surgeons to be performed in total for the patients and all of the surgical procedures performed during the surgery. For statistical analysis, a conversion as present/yes $=1$ and absent/no $=0$ was applied to perform simple statistical analysis for each parameter in the Microsoft Office Excel 2003 program. The program SPSS 11.0.5 for Windows was used for the statistical analysis. Calculation of kappa ( $\kappa$ ) consistency was considered to be statistically convenient in the evaluation of the study results. In this study, we considered the most common usage of intraclass kappa statistic which has been the widely accepted measure for assessing the reliability between two ratings on a binary trait. In a meta-analysis of kappa statistics obtained from multiple studies using the same measure, in multicenter studies or in a stratified study, we would like to compare kappa statistics and present a common or summary kappa agreement using all available information.

\section{Results}

The total number of interventions applied to our patients was 152. The number of interventions planned according to the assessment and performed in compliance with the planning was 121. Although it was planned, intervention was not performed at 33 levels, and despite it was not planned in some cases, intervention was performed at 31 levels. Namely, the pre-operative plans were not carried out at 64 levels. In this case, the probability of being able to perform surgical interventions in compliance with the planning was found to be $65.4 \%$ and kappa ( $\kappa$ ) consistency in the realization by planning and sticking to this plan was found to be $\kappa=0.66$.

Response consistency of each patient for seven different surgical interventions of discectomy, foraminotomy, foraminectomy, laminotomy, laminectomy, flavum excision, and posterior spinal instrumentation at five different spinal surgical levels in the lumbar region was assessed before and after surgery. At this point, lumbar levels that did not plan any surgical intervention in the pre-operative planning were excluded from the calculation to avoid negative affection. However, in the case that the performance of any surgical intervention moved beyond the plan at the levels not planned, a surgical intervention in the pre-operative planning as an out-of-plan procedure, these levels were added to the calculation again. Therefore, a total of 560 different possibilities comprising multiplying the figures of a possible seven different surgical interventions at five different lumbar region levels of 16 patients decreased to 399 possibilities after removal of the levels excluded from the study (Table 1).

Presence of radiculopathy was first assessed with history and physical examination for consistency between planning of radiculopathy and foraminotomy and/or foraminectomy (Table 2). In the planning, one of foraminotomy or foraminectomy should be planned for at least one level. In the assessment performed under these conditions, kappa (к) consistency between the radiculopathy finding and planning of foraminotomy and/or foraminectomy was found to be $\kappa=0.29$. This value was evaluated to be a weak kappa consistency. Consistency between the findings of claudication and laminotomy and/or laminectomy and/or flavum excision interventions was sought (Table 3). Kappa consistency between whether claudication was present or not as a clinical data and pre-operative planning of laminotomy and/ or laminectomy and/or flavum excision interventions was found to be $\kappa=0$. This value was assessed to be inconsistent.

In the following step, according to the questioning order of the surgical intervention performed, consistency was sought between pre-operative and post-operative responses regarding planned and performed discectomy, foraminotomy, foraminectomy, laminotomy, laminectomy, flavum excision, and posterior spinal instrumentation (Table 4).

Table 1. Data used in calculation of consistency for all surgical interventions

Total sum of all surgical interventions

The number of levels performed intervention

\begin{tabular}{|c|c|c|c|c|c|c|}
\hline & \multicolumn{2}{|c|}{ Yes } & \multicolumn{2}{|c|}{ No } & \multicolumn{2}{|c|}{ Total } \\
\hline & Number & Percentage & Number & Percentage & Number & Percentage \\
\hline \multicolumn{7}{|c|}{ The number of levels planned intervention } \\
\hline Yes & 121 & 30.3 & 33 & 8.27 & 154 & 38.59 \\
\hline No & 31 & 7.76 & 214 & 53.63 & 245 & 61.4 \\
\hline Total & 152 & 38.09 & 247 & 61.9 & 399 & 100 \\
\hline
\end{tabular}


Table 2. Data used in calculation of consistency between the presence of radiculopathy and planning of foraminotomy and/or foraminectomy in the patients with radiculopathy

\begin{tabular}{|c|c|c|c|c|c|c|}
\hline \multirow[t]{3}{*}{ Foraminotomy and/or foraminectomy } & \multicolumn{6}{|c|}{ The number of levels performed intervention } \\
\hline & \multicolumn{2}{|c|}{ Yes } & \multicolumn{2}{|c|}{ No } & \multicolumn{2}{|c|}{ Total } \\
\hline & Number & Percentage & Number & Percentage & Number & Percentage \\
\hline \multicolumn{7}{|l|}{ Radiculopathy } \\
\hline Yes & 12 & 75 & 2 & 12.5 & 14 & 87.5 \\
\hline No & 1 & 6.25 & 1 & 6.25 & 2 & 12.5 \\
\hline Total & 13 & 81.25 & 3 & 18.75 & 16 & 100 \\
\hline
\end{tabular}

Table 3. Data used in calculation of consistency between the presence of claudication and planning of laminotomy and/or laminectomy and/or flavum excision in the patients with claudication

\begin{tabular}{|c|c|c|c|c|c|c|}
\hline \multicolumn{5}{|c|}{ Laminotomy and/or laminectomy and/or flavum excision } & & \\
\hline & \multicolumn{2}{|c|}{ Yes } & \multicolumn{2}{|c|}{ No } & \multicolumn{2}{|c|}{ Total } \\
\hline & Number & Percentage & Number & Percentage & Number & Percentage \\
\hline \multicolumn{7}{|c|}{ Claudication } \\
\hline Yes & 11 & 68.75 & 0 & 0 & 11 & 68.75 \\
\hline No & 5 & 31.25 & 0 & 0 & 5 & 31.25 \\
\hline Total & 16 & 100 & 0 & 0 & 16 & 100 \\
\hline
\end{tabular}

Given that there were five lumbar spinal levels, 80 different levels representing a different probability that could be included in the assessment came up. This also represented our total data number. Kappa consistency between the surgeons' plans and the realizations of these plans for surgical interventions of discectomy, laminotomy, and flavum excision was found to be $\kappa=0.66, \kappa=0.70$, and $\kappa=0.73$, respectively. Kappa consistency between the surgeons' plans and the realizations of these plans for surgical interventions of foraminotomy and foraminectomy was found to be $\kappa=0.56$ and $\kappa=0.51$, respectively. This value was considered to represent intermediate kappa consistency. Kappa consistency between the surgeons' plans and the realizations of these plans for surgical intervention of laminotomy was found to be $\kappa=0$. This value was considered to represent complete kappa inconsistency. Kappa consistency between the surgeons' plans and the realizations of these plans for surgical intervention of posterior spinal instrumentation was found to be $\kappa=0.73$. This value was considered to represent a strong kappa consistency.

In the last step, consistency between pre-operative planning of surgical interventions for each level at the lumbar region and the procedures performed during surgery was sought (Table 5). When a total of 16 cases and a proba- ble seven different interventions that might be performed were taken into consideration, 112 different levels were found, each of them representing a different probability. Accordingly, kappa consistency of the surgeons' plans for the vertebral levels of L1-L2, L3-L4, and L4-L5 and the realizations of these plans were found to be $\kappa=0.64, \kappa=0.72$, and $\kappa=0.80$, respectively. These values were considered to represent strong consistency. Kappa consistency of the surgeons' plans for the vertebral levels of L2-L3 and L5-S1 and the realizations of these plans were found to be $\kappa=0.60$ and $\kappa=0.53$, respectively. This value was considered to represent an intermediate kappa consistency. When we investigated the accuracy/error rates of these levels, we observed that the lowest value was at the L5-S1 level similar to kappa calculation. This value was $48.7 \%$. However, the accuracy/ error rate of the L1-L2 level (50\%) was very close to value of the L2-L3 level (51.7\%) apart from the kappa calculation. The rates of the other levels, namely, L3-L4 and L4-L5 levels, were $72.2 \%$ and $80 \%$, respectively.

\section{Discussion}

There are various criteria used for surgical decisions and the choice of surgical application in degenerative spine diseases. ${ }^{[7-9]}$ Excess amount of these criteria can be considered 
Table 4. Data used in calculation of consistency for surgical interventions

\begin{tabular}{|c|c|c|c|c|c|c|}
\hline \multirow[t]{2}{*}{ Intervention } & \multicolumn{4}{|c|}{ The number of levels performed intervention } & & \\
\hline & Number & Percentage & Number & Percentage & Number & Percentage \\
\hline \multicolumn{7}{|l|}{ Discectomy } \\
\hline Yes & 12 & 15 & 9 & 11.25 & 21 & 26.25 \\
\hline \multicolumn{7}{|c|}{ Foraminotomy } \\
\hline Yes & 10 & 12.5 & 7 & 8.75 & 17 & 21.25 \\
\hline No & 4 & 5 & 59 & 73.75 & 63 & 78.75 \\
\hline Total & 14 & 17.5 & 66 & 82.5 & 80 & 100 \\
\hline \multicolumn{7}{|c|}{ Foraminectomy } \\
\hline \multicolumn{7}{|l|}{ Laminotomy } \\
\hline Yes & 0 & 0 & 4 & 5 & 4 & 5 \\
\hline No & 0 & 0 & 76 & 95 & 76 & 95 \\
\hline Total & 0 & 0 & 80 & 100 & 80 & 100 \\
\hline \multicolumn{7}{|l|}{ Laminectomy } \\
\hline Yes & 23 & 28.75 & 2 & 2.5 & 25 & 31.25 \\
\hline No & 9 & 11.25 & 46 & 57.5 & 53 & 68.75 \\
\hline Total & 32 & 40 & 48 & 60 & 80 & 100 \\
\hline \multicolumn{7}{|c|}{ Flavum excision } \\
\hline Yes & 26 & 32.5 & 6 & 7.5 & 32 & 40 \\
\hline
\end{tabular}

as the most important factor for both surgeon-specific interpreting differences in making surgical planning and changing of pre-operative interpretations during the surgery. It is known that the surgeon sometimes takes into account history, or examination findings, or radiological examination findings much more than the others and makes their plan accordingly. ${ }^{[10-12]}$

In the literature search performed, we observed that all consistency investigations in spinal surgery were planned apart from our study. In a group study, the patients proceeded through the questions directed to the different surgeons and their responses. This included evaluating the consistency among the surgeons and between the responses given by them with respect to the parameters investigated. ${ }^{[10,13-17]}$ In a study, the authors directed questions related to five different patient profiles with lumbar disorder on a degenerative disease ground to 22 orthopedics, traumatology specialists, and neurosurgeons and investigated their treatment approaches for five cases; their results showed inconsistencies between the surgeons regarding the patients. They observed that these inconsistencies resulted from the age, experience, and education of the surgeons. ${ }^{[10,14]}$ In our study, the chance for performance of the pre-operative planning of the surgical intervention according to the planning was found to be higher $(65.4 \%)$ in the patients with degenerative lumbar spine disorder. Nevertheless, this percentage shows us clearly how difficult it is to plan degenerative spine surgery and how big the error of margin is. 
Table 5. Data used in calculation of consistency for surgical interventions planned and performed at the L1-S1 level

\begin{tabular}{|c|c|c|c|c|c|c|}
\hline \multirow[t]{2}{*}{ Level } & \multicolumn{4}{|c|}{ The number of levels performed intervention } & & \\
\hline & Number & Percentage & Number & Percentage & Number & Percentage \\
\hline \multicolumn{7}{|l|}{ L1-L2 } \\
\hline Yes & 4 & 3.57 & 3 & 2.67 & 7 & 6.25 \\
\hline \multicolumn{7}{|l|}{ L2-L3 } \\
\hline Yes & 15 & 13.39 & 5 & 4.46 & 20 & 17.85 \\
\hline No & 9 & 8.03 & 83 & 74.1 & 92 & 82.14 \\
\hline Total & 24 & 21.42 & 88 & 78.56 & 112 & 100 \\
\hline \multicolumn{7}{|l|}{ L3-L4 } \\
\hline \multicolumn{7}{|l|}{ L4-L5 } \\
\hline Yes & 44 & 39.28 & 8 & 7.14 & 52 & 46.42 \\
\hline No & 3 & 2.67 & 57 & 50.89 & 60 & 53.56 \\
\hline Total & 47 & 41.95 & 65 & 58.03 & 112 & 100 \\
\hline \multicolumn{7}{|l|}{ L5-S1 } \\
\hline Yes & 19 & 16.96 & 10 & 8.92 & 29 & 25.88 \\
\hline No & 10 & 8.92 & 73 & 65.17 & 83 & 74.09 \\
\hline Total & 29 & 25.88 & 83 & 74.09 & 112 & 100 \\
\hline
\end{tabular}

In our study, consistency between planning foraminotomy and/or foraminectomy in existence of radiculopathy as intervention by the surgeon was found to be weak. Therefore contrary to expectations, it was concluded that the role of radiculopathy in pre-operative planning of foraminotomy and/or foraminectomy was very low. Presence of a radiculopathy finding shows that an inflammatory or compressive event is also involved and is most likely in the nerve root. ${ }^{[18-20]}$ Two types of explanations were considered regarding the results obtained. The first was that the radiculopathy finding in our patients could occur due to inflammation substantially developing on a chronic ground. The second was that this study incorporated only a small number of patients.

When the consistency between findings of claudication and pre-operative planning for surgical interventions of laminotomy and/or laminectomy and/or flavum excision was investigated, claudication was found to be completely inconsistent and in our opinion it was significant. Literature supports the inconsistency found with claudication. Studies show that surgery is typically not performed for claudication, unless it does not cause progressive neurolog- ical deficit or cauda equina, and instead, it is treated with various conservative methods. ${ }^{[21,22]}$ However, there are also opinions that state that neurogenic claudication can be considered as a suitable criterion for selection of patients for surgery. ${ }^{[4,23]}$ For these reasons, we thought that it was impossible to comment within these data. Again, performance of all interventions in 16 patients was considered to be the cause of obtaining a kappa value of 0 .

Due to strong consistency between planning of discectomy and performance of the procedure in compliance with the planning, it can be said that the probability of realization of this surgical planning is high when a surgical discectomy is planned. MRI scans provide detailed information about intervertebral disc herniation. ${ }^{[24-26]}$ Starting from this point of view, it can be interpreted that the surgeons rely on the pre-operative MRI scan findings, but the most reliable parameter for them during surgery is their own observations.

We found an intermediate consistency between planning and realization of foraminotomy and foraminectomy. When we investigated the consistency between pre-operative planning for surgical intervention of laminectomy and 
the surgical procedure performed, we observed that the kappa value was zero. Namely, the result was completely inconsistent. It is quite difficult to provide the required decompression by performing only laminotomy in degenerative spine disorder and spinal stenosis surgery. In this context, not deeming it necessary to perform a laminotomy in all of the patients during the surgery can be explained by this idea. The striking point is again the planning to perform a laminotomy in four of the total 80 levels by the surgeons in pre-operative assessment. Nevertheless, since the surgeons considered that laminotomy was inadequate during the surgery, they preferred to perform laminectomy in all of the levels. Finally, remaining at the forefront of only laminectomy in place of laminotomy in degenerative spine disorder and spinal stenosis surgery seems to be a more realistic approach.

A strong kappa consistency was found between pre-operative planning and performance for interventions of laminectomy, flavum excision, and posterior spinal instrumentation. The surgeons were correcting the instability that could occur after performance of the required decompression with a posterior spinal instrumentation technique. We commented on the higher number of levels performing spinal instrumentation than the number of levels performing laminectomy and/or flavum excision, because they were performed to prevent the possibility of developing spinal instability. Accuracy/error rates of these three surgeons were $67.6 \%, 72.2 \%$, and $81.8 \%$, respectively.

When the consistency between the planning of the surgical interventions for the lumbar regions within themselves as well as their realizations was investigated, we found a strong consistency in the L1-L2, L3-L4, and L4-L5 levels and an intermediate consistency in the L2-L3 and L5-S1 levels. When we investigated the kappa calculations in detail, we observed that a very limited number of surgeries were planned and performed in the L1-L2 level. The reason for this was the lower involvement of the upper lumbar regions than the lower lumbar regions by degenerative disc disease. ${ }^{[18,27]}$ Therefore, slight degeneration of the spine caused less clinical and radiological data, and the surgeons did not include this region in the pre-operative planning. We observed that a lower rate of consistency at the L2-L3 level resulted from realization of interventions, especially laminectomy, flavum excision, and posterior spinal instrumentation out of planning. It was determined that these interventions caused differences as no/yes replies, namely, they were performed by deciding during surgery even though they were not included in the planning. In this case, the probability of including the upper lumbar regions for decompression interventions for upper lumbar region degeneration and stenosis is high, and the surgeon should warn the patient earlier.

In this study, we found the highest consistency at the L2-L3 and L4-L5 levels. Moreover, it was observed that the highest number of surgeries was performed in these levels. More frequent observation of degenerative spinal disease pathologies in the middle lumbar spinal levels also resulted in an increased number of surgical interventions performed at these levels. ${ }^{[28]}$ The L5-S1 level was more inconsistent compared to all other levels. On the other hand, although it was a region exposed to degeneration, interestingly, the L5-S1 level was exposed to less surgery compared to the L3-L4 and L4L5 levels. ${ }^{[28-32]}$ We thought that this inconsistency could result from the surgeons' attempts to preserve this movement at the lumbosacral junction as much as possible. Therefore, this study showed that the choice of any surgical intervention to be performed at any surgical level, such as decisionmaking between foraminotomy and foraminectomy, should be performed carefully and cautiously because both of these conditions include higher error rates.

\section{Conclusion}

The use of only highly experienced spinal surgeons increases the value of the findings of inconsistency determined in this study. The limited number of surgeons and patients gave consistency calculations on different topics based on especially patient number. Studies that include large numbers of surgeons, patients, and/or surgical centers are required to provide more clear data with a wider variety. Probably, by means of these possible studies, degenerative spine surgery will become better planned and therefore exhibit lower error rates and cause less complications and problems in the future.

\section{Disclosures}

Ethics Committee Approval: Council of Higher Education Thesis Number: 267048.

Peer-review: Externally peer-reviewed.

Conflict of Interest: None declared.

Authorship Contributions: Concept - S.A., B.Y., C.K., Ö.A.; Design - S.A., B.Y., C.K., Ö.A.; Supervision - S.A., B.Y., C.K., Ö.A.; Materials - S.A., B.Y., C.K., Ö.A.; Data collection \&/or processing - S.A., B.Y., C.K., Ö.A.; Analysis and/or interpretation - S.A., B.Y., C.K., Ö.A.; Literature search - S.A., B.Y., C.K., Ö.A.; Writing - S.A., B.Y., C.K., Ö.A.; Critical review - S.A., B.Y., C.K., Ö.A. 


\section{References}

1. Canale ST. Lower back pain and disorders of intervertebral discs. In: Williams KD, Park AL, editors. Campbell's Operative Orthopaedics. 10th ed., Vol. 2. United States: Mosby; 2003. p. $1955-65$.

2. Konno S, Kikuchi S, Tanaka Y, Yamazaki K, Shimada Y, Takei $\mathrm{H}$, et al. A diagnostic support tool for lumbar spinal stenozis: A self-administreted,self-reported history questionnaire. BMC Musculoskelet Disord 2007;8:102.

3. Boden SD, Davis DO, Dina TS, Partronas NJ, Wiesel SW. Abnormal magnetic rezonans scans of the lomber spine in asymptomatic subjects: A prospective investigation. J Bone J Joint Surg Am 1990,72:403-8.

4. Moojen WA, Arts MP, Bartels RH, Jacobs WC, Peul WC. Effectiveness of interspinous implant surgery in patients with intermittent neurogenic claudication: A systematic rewiew and metaanalysis. Eur Spine J 2011;20:1596-606.

5. Olmarker K, Holm S, Rosenqvist AL, Rydevik B. Experimental nerve root compression. A model of acute,graded compression of the porcine cauda equina and an analysis of neural and vascular anatomy. Spine 1991;16:61-9.

6. Alicioglu B, Yilmaz B, Bulakbasi N, Copuroglu C, Yalniz E, Aykac B, et al. Magnetic resonance imaging predictors of surgical outcome in degenerative lumbar spinal stenosis. Jpn J Radiol 2012;30:811-8.

7. Detsky AS. Regional variation in medical care. N Engl J Med 1995;333:589-90.

8. Willems P. Decision making in surgical treatment of chronic low back pain: The performance of prognostic tests to select patients for lumbar spinal fusion. Acta Orthop Suppl 2013;84:135.

9. Boakye M, Mindea S. Inclusion of asymptomatic degenerative discs in a two-level anterior cervical discectomy and fusion: A decision analysis. World Neurosurg 2012;78:339-43.

10. Irvin ZN, Hilibrand A, Gustavel M, McLain R, Shaffer W, Myers $\mathrm{M}$, et al. Variation in surgical decision making for degenerative spinal disorders. Part 1: Lumbar spine. Spine (Phila Pa1976) 2005;30:2208-13.

11. Jonnson B, Stromqvist B. Symptoms and signs in degeneration of the lumbar spine: A prospective, consecutive study of 300 operated patients. J Bone J Joint Surg Br 1993;75:381-4.

12. Pheasant HC, Dyck P. Failed lumbar disc surgery: Cause assesment,treatment. Clin Orthop Relat Res 1982;164:93-109.

13. Wiesel SW, Tsournas N, Feffer HL, Citrin CM, Patronas N. A study of computer-assisted tomography. The indicence of positive CAT scans in an asymptomatic group of patients. Spine 1984;9:549-51.

14. Irvin ZN, Hilibrand A, Gustavel M, McLain R, Shaffer W, Myers $\mathrm{M}$, et al. Variation in surgical decision making for degenerative spinal disorders. Part 2: Cervical spine. Spine (Phila Pa 1976) 2005;30:2209-14.

15. Donaldson S, Stephens D, Howard A, Alman B, Narayanan U, Wright JG. Surgical decision making in adolescent idiopathic scoliosis. Spine (Phila Pa 1976) 2007;32:1526-32.
16. Donaldson S, Hedden D, Stephens D, Alman B, Narayanan U, Wright JG. Surgeon reliability in rating physical deformity in adolescent idiopathic scoliosis. Spine (Phila Pa 1976) 2007;32:363-7.

17. Aubin CE, Labelle H, Ciolofan OC. Variability of spinal instrumentation configurations in adolescent idiopathic scoliosis. Eur Spine J 2007;16:57-64.

18. Valat JP, Genevay S, Marty M, Rozenberg S, Koes B. Sciatica. Best Pract Res Clin Rheumatol 2010;24:241-52.

19. Govind J. Lumbar radicular pain. Aust Fam Physician 2004;33:409-12.

20. Ma C, Greenquist KW, Lamotte RH. Inflammatory mediators enhance the excitability of chronically compressed dorsal root ganglion neurons. J Neurophysiol 2006;95:2098-107.

21. Atlas SJ, Delitto A. Spinal stenosis: Surgical versus nonsurgical treatment. Clin Orthop Relat Res 2006;443:198-207.

22. Comer CM, Redmond AC, Bird HA, Conaghan PG. Assesment and management of neurogenic claudication associated with lumbar spinal stenosis in a UK primary care musculoskeletal service: A survey of current practice among physiotherapists. BMC Musculoskelet Disord 2009;10:121.

23. Han IH, Suh SH, Kuh SU, Chin DK, Kım KS. Types and prevalence of coexisting spine lesions on whole spine sagittal MR images in surgical degenerative spinal diseases. Yonsei Med J 2010;51:414-20.

24. Lurie JD, Tosteson AN, Tosteson TD, Carragee E, Carrino JA, Kaiser J, et al. Reliability of magnetic resonance imaging readings for lumbar disc herniations in the Spine patient outcomes research trial (SPORT). Spine (Phila Pa 1976) 2008;33:991-8.

25. Herzog RJ, Guyer RD, Graham-Smith A, Simmond ED Jr. Magnetic resonance imaging. Use in patient with low back or radicular pain. Spine (Phila Pa 1976) 1995;20:1834-8.

26. Modic MT, Ross JS. Magnetic resonance imaging in the evaluation of low back pain. Orthop Clin North Am 1991;22:283-301.

27. Ong A, Anderson J, Roche J. A pilot study of the prevalence of lumbar disc degeneration in elite athletes with lower back pain at the Sydney 2000 olympic games. Br J Sports Med 2003;37:263-6.

28. DeCandido P, Reinig JV, Dwyer AJ, Thompson KJ, Ducker TB. Magnetic resonance assessment of the distribution of lumbar spine disc degenerative changes. J Spinal Disoard 1988;1:9-15.

29. Bridwell KH, Sedgewick TA, O’Brien MF, Lenke LK, Baldus C. The role of fusion and instrumentation in the treatment of dejenerative spondylolisthesis with spinal stenosis. J Spianal Disord 1993;6:461-72.

30. Fitzgerald JA, Newman PH. Degenerative spondylolisthesis. J Bone Joint Surg 1976;58:184-92.

31. Liu H, Li S, Wang J, Wang T, Yang H, Li Z, et al. An analysis of spinopelvic sagittal alignment after lumbar lordosis reconstruction for degenerative spinal diseases: How much balance can be obtained? Spine (Phila Pa 1976) 2014;39:S190-7.

32. Herkowitz HN, Kurtz LT. Degenerative lumbar spondylolisthesis with spinal stenosis: A prospective study comparing decompression with decompression and intertransverse process artrodesis. J Bone Joint Surg 1991;73:802-8. 